\title{
Smoking Prevalence and Associated Factors among Students of Balıkesir University
}

\author{
Nurhan Sarıoğlu ${ }^{1}$, Coşkun Cüce², Fuat Erel ${ }^{1}$, Mehmet Köse $^{1}$, Mehmet Arslan², $^{2}$ \\ Abdurrahman Said Bodur²
}

${ }^{1}$ Department of Chest Diseases, Balıkesir University School of Medicine, Balıkesir, Turkey

${ }^{2}$ Department of Public Health, Balıkesir University School of Medicine, Balıkesir, Turkey

\begin{abstract}
Objective: This study aimed to investigate the smoking prevalence and associated factors among the students of Balıkesir University and determine the level of nicotine dependence in smokers.

Methods: Six faculties and two graduate schools located at the Balıkesir University campus were enrolled. The cluster method was used as the sampling method. To observe the rates of smoking initiation while studying at the university, first-year and final year students were compared.

Results: A total of 1096 students were enrolled, with a mean age of $20.4 \pm 2.2$ years. The regular smoking prevalence rate was $25.5 \%$, occasional smoking rate was $9.5 \%$, alcohol consumption rate was $28.0 \%$, and drug abuse rate was $5.0 \%$. The mean age for attempting to smoke was $16.6 \pm 2.2$ years. The leading causes of smoking were curiosity, spiritual space, affection, and to comply with friends. According to the Fagerström questionnaire, the level of nicotine dependence was low in $53.0 \%$ of the participants, moderate in $8.7 \%$, and high in $28.4 \%$. The average smoking prevalence rate was $23.6 \%$ in first-grade students, whereas it was $44.8 \%$ in last-grade students. The factors that influence smoking were as follows: being in the last grade, mother, siblings, and friends who smoke, higher allowance, use of alcohol and drugs. Smoking was found to be more prevalent among males.
\end{abstract}

Conclusion: Last-grade students had a higher smoking prevalence rate than the first-grade students. Family, social environment, and smoking behavior of friends have an influence on smoking. All risk factors, including past history and university period, should be considered together in tobacco control.

Keywords: Risk factors, smoking, university students

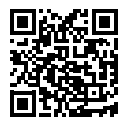

Received Date: 24.08.2015 Accepted Date: 14.11 .2015 Available Online Date: 11.01.2016

DOI: $10.5152 /$ ejp.2015.63644

Correponding Author

Nurhan Sarığlu

E-mail: nurhangencer@hotmail.com

- Available online at www.eurasianjpulmonol.com 4.0 International License.

\section{INTRODUCTION}

Addition to smoking is the leading cause of morbidity and mortality, which can be prevented. Approximately 820 million men and 176 million women smoke worldwide (1), and approximately 6 million individuals die because of tobacco use annually (2). The increase in the global tobacco epidemic resulted in the World Health Organization (WHO) undertaking measures to control tobacco use. For this purpose, WHO initiated the Framework Convention on Tobacco Control for signing in 2003. Turkey accepted this contract in 2004 (3). Moreover, the MPOWER package containing six basic strategies regarding tobacco control was published by WHO in 2008 (4). In the 2013 report of the global tobacco epidemic, Turkey was reported to be the first and only country that applied this project at the highest levels by fulfilling five of the six basic strategies and was an example to other countries (5).

One of the MPOWER strategies is the monitoring and evaluation of tobacco use and protective applications. For this purpose, the Global Adult Tobacco Survey (GATS) is performed. According to the latest GATS performed in our country, the prevalence of tobacco use among adults aged $\geq 15$ years was found to be $27.1 \%$ (6), which corresponds to 14.8 million adults. The rate of tobacco use in the age group of 15-24 years was found to be $20 \%$, according to the report. One in every five young individuals in this age group is a smoker. The highest number was found in the age group of 25-44 years and the lowest in the age group of $\geq 65$ years. 
University students represent the majority of young individuals who smoke. During the university period, being away from home, reduced family control, and social factors, such as the desire to fit in a circle of friends or prove himself/herself as capable, may lead a person to smoke. This study aimed to investigate the prevalence of smoking and its associated factors among the students of the Balıkesir University.

\section{METHODS}

This was a cross-sectional descriptive study, which aimed to investigate the smoking habits of university students, examine the factors affecting this habit, and determine the nicotine dependence level (NDL) among smokers. At the same time, the views and recommendations of students regarding the legal regulations that are related to smoking and the fight against cigarettes were also investigated. The study was approved by the University Clinical Research Ethics Committee and permission was obtained from the University rectoral office.

The study population included university students studying in the faculties of medicine, tourism, economics and administrative sciences, science and literature, veterinary medicine, engineering, and architecture and the health occupation school in the Balıkesir University campus. Two groups of students studying in the first and final years at the university were included in the study. For sampling, the cluster method was used. Each class was regarded as a cluster. The sample size was calculated using the software program Power and Sample Size Analysis Software 11. Because the prevalence of smoking was predicted to be $30 \%$, the sample size for a $95 \%$ confidence interval that would keep within $\pm 20 \%$ of the relative deviation was calculated to be 239 for each group. As the cluster method was implemented for sample selection, the cluster design effect was taken to be 2. By multiplying the existing 239 samples by the design effect, at least 478 individuals for each group were targeted for inclusion in this study. Because the number of students in the vocational school, faculty of engineering and architecture, and faculty of science and literature were approximately more than twice compared with the other faculties, a total of 200 students from each of the abovementioned faculty were targeted and 100 students were targeted from other faculties. After determining the number of samples, schools, and classes to introduce the survey in, the schools were determined using the simple random method. Fieldwork was conducted between May 1 and 15, 2014. Finally, 1096 students were included, of which 505 were in first year and 591 were in their final year.

To evaluate NDL, a 27-item questionnaire prepared by us and the 6-question Fagerstrom test were given to the students (7). NDL was classified as very low (0-2), low (3-4), medium (5), high (6-7), and very high (8-10) based on the scores of the students in this test. To assess the knowledge of students, they were questioned regarding the diseases caused by smoking.

Independent Variables: Were those related to the student such as age, gender, field, class, employment status, place of residence, maternal and paternal education level, smoking causes, smoking characteristics and identities of other family smokers, smoking status of friends, monthly pocket money, school performance, alcohol consumption, knowledge of the dangers of smoking, student's attempt at drug use, and NDL.

The Dependent Variable: Was the presence of smoking. Those who answered "I smoke regularly" in the survey were accepted as smokers, whereas those who answered "I have never smoked", "I tried but did not like it", "I sometimes smoke", and "I quit" were considered as non-smokers.

After the necessary explanations were provided and verbal consent was obtained, data were recorded by filling out the previously prepared questionnaires. Names were not written on the questionnaires, and the students were told that the results would not be given to their families and school.

\section{Statistical Analysis}

The statistical software SPSS version 20.0 (Statistical Package for the Social Sciences Inc.; Chicago, IL, USA) was used for data analysis. Univariate Chi-square test was used to determine the effect of the independent variable on the dependent variable while detecting the causes affecting a student's smoking status. Independent variables wherein significant levels of correlation were detected with the Chisquare test were evaluated using the backward method and logistic regression analysis. The significance level was a $p$ value of $<0.05$.

Table 1. The distribution and the rates of smoking of students according to faculties

\begin{tabular}{|c|c|c|c|c|c|}
\hline \multirow[b]{2}{*}{ Faculty } & \multicolumn{2}{|c|}{ First year } & \multicolumn{3}{|c|}{ Final year } \\
\hline & Number & Smoker n (\%) & Number & Smoker n (\%) & $p$ \\
\hline Medicine & 59 & $5(8.5)$ & 59 & $6(10.2)$ & 0.104 \\
\hline Tourism & 46 & $15(32.6)^{*}$ & 49 & $28(57.1)^{\#}$ & 0.002 \\
\hline Health High School & 66 & $4(6.1)$ & 61 & $9(14.8)$ & 0.006 \\
\hline Economics and Administrative Sciences & 49 & $10(20.4)$ & 43 & $11(25.6)$ & 0.861 \\
\hline Science and Literature & 103 & $13(12.6)$ & 110 & $34(30.9)$ & 0.001 \\
\hline Veterinary & 28 & $5(17.9)$ & 49 & $19(38.8)^{\# \# \#}$ & 0.026 \\
\hline Engineering and Architecture & 98 & $21(21.4)^{* * *}$ & 99 & 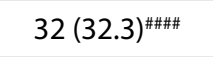 & 0.001 \\
\hline Vocational School & 56 & $18(32.1)^{* *}$ & 121 & $49(40.5)^{\# \#}$ & 0.057 \\
\hline Total & 505 & 119 & 591 & 265 & $<0.001$ \\
\hline \multicolumn{6}{|c|}{ 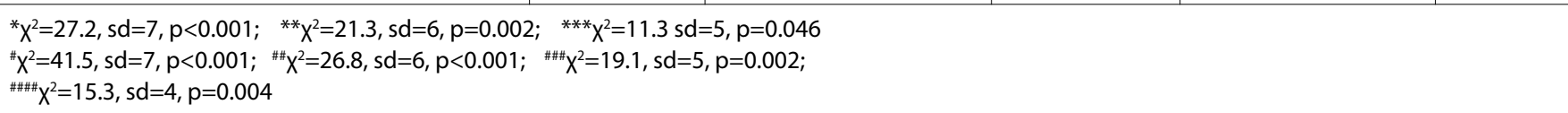 } \\
\hline
\end{tabular}




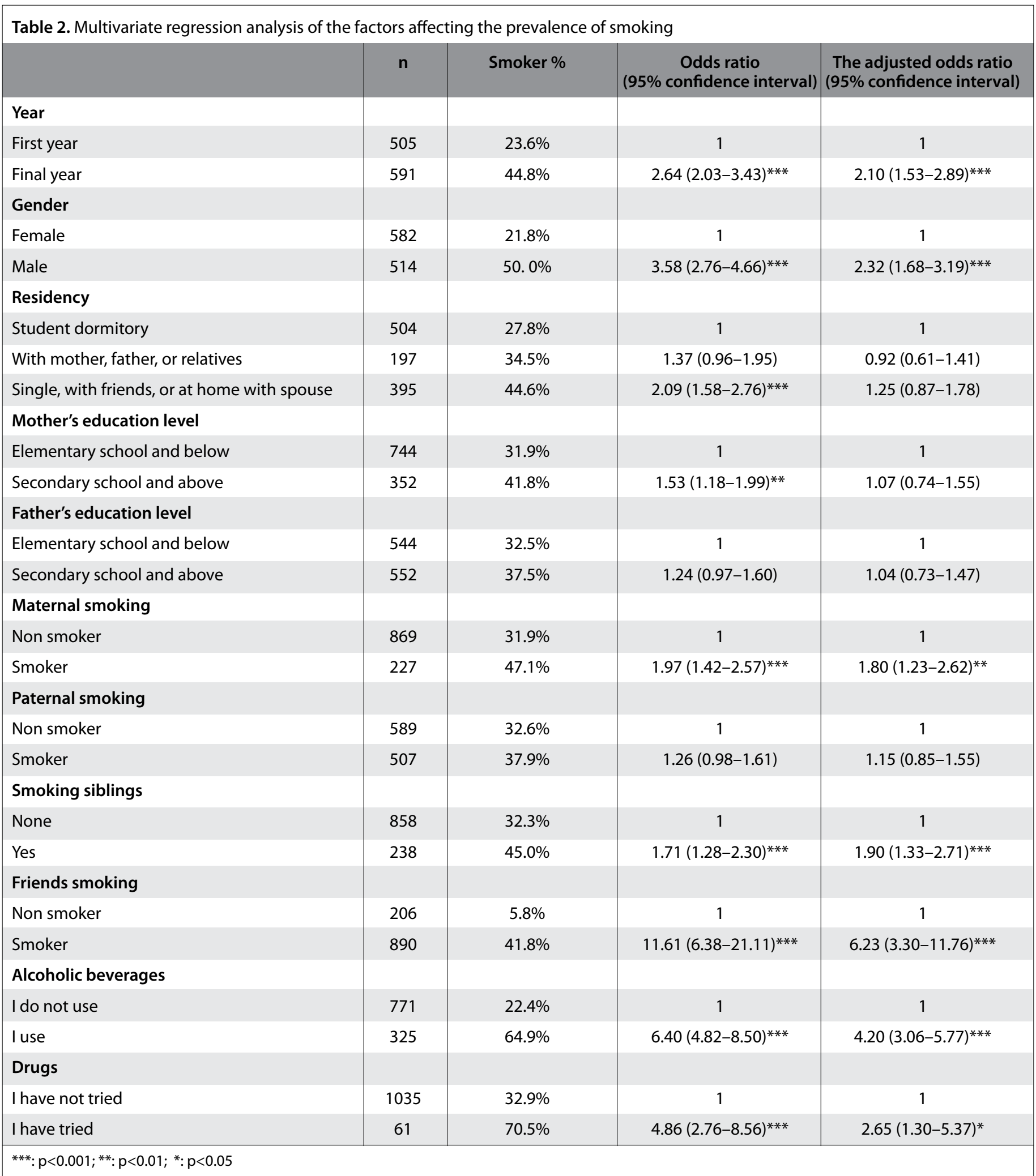

\section{RESULTS}

Six schools and two colleges participated in the study. Regular smokers constituted $25.5 \%$ (279), and those who said "I occasionally smoke" were 9.5\% (103), "I tried but didn't like it" were 14.4\% (158), "I quit" were $2.2 \%$ (24), and "I have never smoked" were $48.5 \%$ (532). Of all students, 53.1\% (582) were females and 46.9\% (514) were males. The mean age was $20.4 \pm 2.2$ years. The age at which students started smoking was $16.6 \pm 2.2$ years. Among the reasons to start smoking, curiosity ranked first, followed by psychological emptiness and emulation and adaptation to friends. Moreover, $46.1 \%$ (505) of students were in their first year and $53.9 \%$ (591) in their final year. The rates of smoking with respect to the faculties are shown in Table 1. The rates of smoking were found to be significantly higher in the tourism school (32.6\%), vocational school (32.1\%), and faculty of engineering 
and architecture (21.4\%) than in other faculties. Among the students in their final year, the rates of smoking were found to be higher in the tourism school (57.1\%), vocational school (40.5\%), faculty of veterinary medicine $(38.8 \%)$, and faculty of engineering and architecture $(32.2 \%)$ than in other faculties. The lowest rates of smoking were observed among students in the faculty of medicine and vocational health high school. When we compared the faculties among themselves, the rates of smoking were found to be higher in the final-year students than in the first-year students for all schools. While this increase does not reach a statistically significant level in the faculty of medicine, faculty of economics and administrative sciences, and vocational high school, the increase in the rates of smoking among the final-year students demonstrated statistical significance in all other schools $(p<0.05)$ (Table 1$)$.

While the average prevalence of smoking was $23.6 \%$ in the first-year students, it was $44.8 \%$ in the final-year students. The rate of smoking was higher in male students (50.0\%) than in female students $(21.8 \%)$ $(p<0.001)$. Being a final-year student increased the risk of smoking by 2.1 times and being a male increased it by 2.3 times [ $95 \%$ confidence interval (Cl): 1.53-2.89 and 1.68-3.19, respectively] (Table 2). While maternal smoking increased the risk of smoking by 1.8 times $(95 \%$ $\mathrm{Cl}, 1.23-2.62)$, paternal smoking had no effect. As a mother's education level increased, the rate of smoking also increased; however, the effect was dependent on other variables. A father's educational level did not affect smoking. Smoking siblings increased the risk of smoking by 1.9 times $(95 \% \mathrm{Cl}, 1.33-2.71)$. Furthermore, the cause that increased the risk of smoking most was smoking friends (6.23fold; $95 \% \mathrm{Cl}$, 3.30-11.76). Alcohol and drug use were other important factors that increased the risk of smoking. Moreover, $29.7 \%$ (325) of students consumed alcohol and 5.6\% (61) had tried drugs. The rates of smoking were significantly higher in students who had an allowance of $\geq 500$ Turkish Lira than those who received less allowance $(p<0.001)$.

While $32.7 \%$ (127) of students gave the answer "yes" to the question "Do you want to stop smoking," 25\% (97) said "no", 21.4\% (83) said "I would like to but I cannot succeed somehow", and $20.9 \%$ (81) replied "I have never thought of it". Further, $24.1 \%$ of students attempted to quit smoking at least once, $27.1 \%$ attempted $2-5$ times, $15.9 \%$ attempted more than 5 times.

According to the Fagerstrom questionnaire by which we examined the dependence level, low levels of dependency were found in $53.0 \%$ of students who smoked, medium levels in $8.7 \%$, and high levels in $28.4 \%$.

While $23.9 \%$ of students wanted to smoke in the canteens and cafeterias on campus, $76.1 \%$ said they did not. While $51.6 \%$ of students found the implemented bans for a smoke-free society sufficient, $48.4 \%$ stated that they were insufficient. The most incentivizing applications for smoking cessation were reported to be a smoking ban in enclosed places $(60.0 \%)$, warnings issued by health professionals (26.0\%), warnings on television (25.9), and warnings in printed publications (14.9\%).

In the questions regarding the effects of smoking on health, osteoporosis was the least known health risk.

\section{DISCUSSION}

The prevalence of smoking ranged from $81.8 \%$ to $27.9 \%$ in similar studies investigating the prevalence among university students (8-12).
Of all students who participated in our study, $35 \%$ were smokers. The rate of regular smoking was found to be $25.5 \%$. The prevalence of tobacco use in adults aged between 15 and 24 years was reported to be $20.0 \%$ from the latest GATS report (6). As in many studies conducted in our country, the prevalence of smoking was higher in men than in women in our study also (8-14). The average age to start smoking among university students has been reported to be between 14 and 16 years in previous surveys (9-13). In this study, the age at which students started to smoke was $16.6 \pm 2.2$ years. Although there is a ban on selling cigarettes to those aged $<18$ years, these results demonstrated that this age group was still able to access cigarettes. The rate of smoking in students with good economic status was high. Relative wealth was also positively linked to increased accessibility of cigarettes. One of the strategies stated in the Framework Convention on Tobacco Control and the MPOWER package is to increase the tax on tobacco products. While the accessibility of cigarettes to young individuals is reduced with this countermeasure, in other respects, providing education regarding smoking at schools during childhood and adolescence may better contribute to the fight against smoking.

The prevalence of tobacco use in Turkey is increasing in parallel with education levels. The lowest prevalence was found in women having no education in the rural areas, while the highest prevalence was found in both men and women who were high school graduates (6). Some studies that were conducted with university students reported that no relationship was observed between the parents' education level and cigarette smoking (9-11), while a correlation was detected in some studies (12). In our study, as the education level of the mother increased, tobacco use also increased. This situation may be associated with the fact that mothers with an increased education level smoke more. In this study, while maternal smoking increased the risk of smoking of the child, paternal smoking did not have a similar effect. This result demonstrated that children take mothers as a role model more when they start to smoke. Another important factor in the family was the smoking status of siblings. The rate of smoking increased in students who had smoking siblings.

While factors in the family environment have an influence in childhood, friends have a more significant influence in the socialization process, particularly during youth. In this study, the factor that most increased tobacco use (6.23 times) was smoking friends. In the study conducted with college students in İstanbul, Aktürk et al. (15) showed that smoking friends increased the risk of smoking by 8 times. Tanrıkulu et al. (11) reported that as the number of friends who smoked increased, the risk of smoking also increased. In other studies, a strong relationship was found between smoking behavior and close friends $(12,16-18)$.

A positive correlation was found between the use of alcohol and drugs and smoking in many studies (19-23). Bugdayci et al. (19) reported that alcohol use increased the rate of smoking by 6.1 times. In another study conducted in Canada, alcohol consumption was higher in smokers and concurrent smoking with alcohol use was high (20). In our study, a strong correlation was found between smoking and the use of alcohol and drugs. Curiosity, psychological emptiness, emulation, and adaptation to friends were reported among the most common causes for starting to smoke.

Final-year students and freshmen were compared in our study in terms of the rates of smoking. While the frequency of smoking in students studying in the first year was $23.6 \%$, in the final year, it was $44.8 \%$. There are few studies comparing the first- and final-year stu- 
dents in the literature. Özcebe et al. (12) demonstrated that while the prevalence of smoking in the first-year students was $19.7 \%$, it was $28.6 \%$ in the final-year students. Göktalay et al. (24) reported that the rate of smoking increased in third- and fourth-year students of the health high school and the faculty of medicine after 2 years of observation. The rates of smoking were higher in the final-year students than in the first-year students in all faculties participating in our study. This result suggests possible factors affecting tobacco use with respect to the university environment. During this period, trying to join a social environment, freedom of being away from the family, spending more time with friends, and factors such as using common areas (cafeterias and canteens) may be factors that trigger smoking. In addition, finishing school and employment concerns may be other causes for smoking in graduating students.

A difference in the rates of smoking among schools was detected in studies were carried out abroad $(11,12,23)$. In a study conducted in the UK, while the prevalence of smoking in those studying arts and social sciences was high, it was found to be lower in the students of engineering, faculty of veterinary and medicine (23). In the study conducted with the students in Kars, a higher rate of smoking was found in those studying social sciences than those studying the physical sciences (11). While the lowest rate of smoking in our study was found in the faculty of medicine and health high school, the highest rates were found in the tourism and vocational schools. Differences among faculties, even in the starting classes, show that pre-entrance factors also play a role. In the research done with the students of faculty of medicine of Düzce, the rates of smoking changed according to the high school they graduated from. It was demonstrated that the prevalence of smoking in Science High School graduates was the highest (25). Starting smoking usually occurs during adolescence. Therefore, a wider coverage should be given to education about smoking in high school years.

Unlike many other studies conducted with university students, NDL was evaluated in our study. Accordingly, low levels of dependence were detected in $53 \%$ of the students, moderate levels in $8.7 \%$ and high levels in $28.4 \%$. Nicotine addiction in Turkey was found at a very high level according to the GATS report (6). According to this, more than half of smokers (56.0\%) consume over 16 cigarettes a day and $41.1 \%$ of smokers smoke the first cigarette of the day within half an hour after waking up. Lower levels of addiction in our study suggest that the dependency level in young individuals is less than the general population. If smoking cessation is successful in the younger population, the rates of smoking will be reduced in the future for middle-aged and older groups. Most of the students in our study group of smokers (65.5\%) had previously attempted to quit. Students who smoke and want to quit were directed to the smoking cessation clinics in the Department of Chest Diseases.

While nearly half of the students (51.0\%) found the sanctions and bans imposed for a smoke-free society sufficient, the others stated that they found them insufficient. The most encouraging application was stated to be the ban of smoking in closed places. A campaign for a "Smoke-Free Zone" was initiated with laws enacted in 2008 in Turkey and the application was expanded to include all indoor areas in 2009 (restaurants, cafes, bars, and cafes) (26). In research performed on university students and academic staff to evaluate the new tobacco laws, Gelen et al. (27) showed that $85.7 \%$ of the university students and $93.1 \%$ of the academic staff supported this law. After the law was enacted, $68.1 \%$ of participants in this study reported that they enjoyed going to places where smoking is banned much more.
In our study, $76.1 \%$ of the students stated that they did not want individuals to smoke in the canteens and cafeterias of the campus. The most frequent answer given to the question "What do you think can be done for a smoke-free society?" was that prohibitions, sanctions, and inspections should be increased. This result suggests that there are deficiencies in applying the prohibitions.

There are some limitations to our study. One limitation was that students attending evening education did not participate in the study. Because of the small number of students in this group, it was not investigated. The second is that internal factors within faculties were not examined. These are factors such as admission numbers, number of students in each class, number of social areas, lesson hours per week, and drop-out rates.

\section{CONCLUSION}

The rates of smoking of students in the Balıkesir University were found to be similar to other universities in our study. Addiction levels in students were lower than found for the general population. The rates of smoking increased in university students toward the end of their education. Education about smoking was given in the faculty of medicine and health high schools, but campaigns and activities should also be planned to raise awareness about smoking in the other faculties. Our study has a cross-sectional characteristic and observational studies of 2-4 years are needed where the same students are followed for the long term.

Ethics Committee Approval: Ethics committee approval was received for this study from the ethics committee of Balıkesir University.

Informed Consent: Informed consent was obtained from students who participated in this study.

Peer-review: Externally peer-reviewed.

Author Contributions: Concept - N.S., A.S.B., F.E.; Design - A.S.B., N.S., C.C.; Supervision - N.S., F.E., M.K.; Resources - M.K., M.A., C.C.; Materials - C.C., M.A., N.S.; Data Collection and/or Processing - C.C., M.A., M.K., N.S.; Analysis and/ or Interpretation - A.S.B., C.C., M.A.; Literature Search - N.S., F.E., M.K.; Writing Manuscript - N.S., A.S.B., F.E.; Critical Review - F.E., A.S.B., N.S.

Conflict of Interest: No conflict of interest was declared by the authors.

Financial Disclosure: The authors declared that this study has received no financial support.

\section{REFERENCES}

1. Eriksen M, Mackay J, Schluger N, Gomeshtapeh FI, Drope J. The Tobacco Atlas - Fifth edition. The American Cancer Society. Atlanta, Georgia 30303 USA 2015; 18-20.

2. WHO global report on trends in prevalence of tobacco smoking. World Health Organization, March 2015.

3. Dünya Sağlık Örgütü Tütün Kontrolü Çerçeve Sözleşmesinin Onaylanmasının Uygun Bulunduğuna Dair Kanun. T.C. Resmî Gazete, 30 Kasım 2004: 25656 (http://rega. basbakanlik.gov.tr/main.aspx?home=http://rega.basbakanlik.gov.tr/eskiler/2004/11/20041130.htm\&main=http://rega.basbakanlik.gov.tr/eskiler/2004/11/20041130.htm, son erişim tarihi: 14 Eylül 2015).

4. WHO Report on the Global Tobacco Epidemic, 2008: The MPOWER Package. Geneva, World Health Organization, 2008. (http://www.who.int/ tobacco/mpower/ 2008/en/ index.html, Erişim Tarihi: 15.06.2012).

5. WHO Report on the Global Tobacco Epidemic, 2013. Enforcing bans on tobacco advertising, promotion and sponsorship. World Health Organization, 2013 (www.who.int/tobacco/global_report/en/ index. html, Erişim Tarihi 10.06.2013).

6. Küresel Yetişkin Tütün Araştırması Türkiye 2012. Sağlık Bakanlığı Yayın No: 948, Ankara, 2014. 
7. Heatherton TF, Kozlowski LT, Frecker RC, Fagerström KO. The Fagerström Test for Nicotine Dependence: a revision of the Fagerström Tolerance Questionnaire. Br J Addict 1991; 86: 1119-27. [CrossRef]

8. Gündüz Telli C, Aytemur Solak Z, Özol D, Sayıner A. Smoking habits among newly registered university students. Eurasian J Pulmonol 2004; 6: 101-6.

9. Ceylan E, Yanık M, Gencer M. Harran Üniversitesi'ne kayıt yaptıran öğrencilerin sigaraya karşı tutumlarını etkileyen faktörler. Turk Thorac J 2005; 6: 144-50.

10. Boyacı H, Çorapçıŏlu A, Ilgazlı A, Başyiğit İ, Yıldız F. Kocaeli üniversitesi öğrencilerinin sigara içme alışkanlıklarının değerlendirilmesi. Solunum Hastalıkları 2003; 14: 169-75.

11. Tanrıkulu Ç, Çarman KB, Palancı Y, Çetin D, Karaca M. Kars il merkezinde çeşitli üniversite öğrencileri arasında sigara kullanım sıklığı ve risk faktörleri. Turk Thorac J 2009; 3: 101-6.

12. Özcebe H, Doğan BG, İnal E, Haznedaroğlu D, Bertan M. Üniversite öğrencilerinin sigara içme davranışları ve ilişkili sosyodemografik özellikleri. Turk Thorac J 2014; 15: 42-8.

13. Bayrak U, Gram E, Mengeş E, Okumuş ZG, Sayar HC, Skrijelj E, et al. Üniversite öğrencilerinin sağlıkla ilgili alışkanlıklar ve kanser konusundaki bilgi ve tutumları. DEÜ Tıp Fakültesi Dergisi 2010; 24: 95-104.

14. Akçay Ş, Dilektaşıı Görek A, Budakoğlu I, Yılmaz I, Erdem Ö. Attitudes and knowledge for smoking among university students. Turkiye Klinikleri J Med Sci 2009; 29: 611-7.

15. Aktürk ÜA, Içmeli ÖS, Öztaş S, Koçak ND, Şengül A, Salepçi BM, et al. Evaluation of Cigarette Smoking Attitudes and Behaviors Among Students of a State High School in İstanbul. Eurasian J Pulmonol 2015; 17: 107-11. [CrossRef]

16. Gaeta G, Del Castello E, Cuomo S, Effuso L, Boccalatte A. Family and friends who smoke: influence on adolescents. G Ital Cardiol 1998; 28: 259-66.

17. de Vries H, Engels R, Kremers S, Wetzels J, Mudde A. Parents and friends smoking status as predictors of smoking onset: findings from six Europe- an countries. Health Educ Res 2003; 18: 627-36. [CrossRef]

18. Oksuz E, Mutlu ET, Malhan S. Characteristics of daily and occasional smoking among youths. Public Health 2007; 121: 349-56. [CrossRef]

19. Bugdayci R, Sasmaz T, Aytac N, Camdeviren H. The factors affecting alcohol consumption prevalence in three sports academies in Adana, Mersin and Hatay. Turkiye Klinikleri J Med Sci 2003; 23: 208-12.

20. McKee SA, Hinson R, Rounsaville D, Petrelli P. Survey of subjective effects of smoking while drinking among college students. Nicotine Tob Res 2004; 6: 111-7. [CrossRef]

21. Hines D, Fretz AC, Nollen NL. Regular and occasional smoking by college students: Personality attributions of smokers and nonsmokers. Psychol Rep 1998; 83: 1299-306. [CrossRef]

22. Keskinoğlu P, Karakuş N, Pıçakçıefe M, Giray H, Bilgiç N, Kılıç B. İzmir'de lise öğrencilerinde sigara içme sıklığı ve içicilik davranışı üzerine sosyal öğrenmenin etkisi. Turk Thorac J 2006; 7: 190-5.

23. Webb E, Ashton H, Kelly P, Kamali F. Patterns of alcohol consumption, smoking and illicit drug use in British university students: interfaculty comparisons. Drug Alcohol Depend 1997; 47: 145-53. [CrossRef]

24. Göktalay T, Cengiz Özyurt B, Sakar Coşkun A, Celik P. Level of smoking of 3rd and 4th grade students studying health and related factors: follow-up study. Tuberk Toraks 2011; 59: 355-61. [CrossRef]

25. Mayda SA, Tufan N, Baştaş S. Düzce Tıp Fakültesi Öğrencilerinin Sigara Konusundaki Tutumları ve İçme Sıklıkları. TAF Prev Med Bull 2007; 6: 364-70.

26. 16.07.2009 tarih ve 4207 sayılı Tütün Mamullerinin Zararlarının Önlenmesi ve Kontrolü Hakkında Kanun. Resmi Gazete; 16 Temmuz 2009-27290.

27. Gelen ME, Köksal N, Ozer A, Atilla N, Cinkara M, Kahraman H, et al. The assessment of knowledge about recent tobacco law number 5727 among our university students, academic and administrative staff. Tuberk Toraks 2011; 59: 132-9. [CrossRef] 